\title{
ANALISIS PENGETAHUAN DAN SIKAP MASYARAKAT TERHADAP PERILAKU UPAYA PENCEGAHAN PENYAKIT MALARIA DI PUSKESMAS KONI KOTA JAMBI
}

\author{
Analysis Of Knowledge And Community Attitude On The Behavior Of Malaria Disease \\ Prevention Efforts In Koni Health Center Of Jambi City
}

\author{
Dwi Noerjoedianto ${ }^{1}$
}

${ }^{1}$ Dosen Prodi Kesehatan Masyarakat Fakultas Kedokteran dan Ilmu Kesehatan Universitas Jambi

\begin{abstract}
ABSTRAK
Berdasarkan data yang didapat di Dinas Kesehatan Kota Jambi pada tahun 2012 di 20 Puskesmas dengan AMI yaitu 13,57\% dengan kasus berjumlah 7300 kasus. Penelitian dilakukan di wilayah kerja Puskesmas Koni Kota Jambi bertujuan untuk mengetahui hubungan antara variabel independen (Pengetahuan dan Sikap) dengan variabel dependen (Perilaku Upaya Pencegahan Penyakit Malaria), dengan jumlah sampel sebesar 105 responden. Penelitian merupakan penelitian kuantitatif dengan desain cross secsional. Dari 36 responden yang memiliki pengetahuan rendah, 52,5\% responden mempunyai perilaku pencegahan penyakit malaria yang kurang baik dan $10,9 \%$ responden mempunyai perilaku pencegahan penyakit malaria yang baik. Sedangkan dari 69 responden yang memiliki pengetahuan tinggi, 47,5\% responden mempunyai perilaku pencegahan penyakit malaria kurang baik dan $89,1 \%$ responden mempunyai perilaku pencegahan penyakit malaria yang baik dengan p-value 0,000 . Sedangkan dari 71 responden yang memiliki pengetahuan rendah, 83,1\% responden mempunyai perilaku pencegahan penyakit malaria yang kurang baik dan 47,8\% responden mempunyai perilaku pencegahan penyakit malaria yang baik. Sedangkan dari 34 responden yang memiliki pengetahuan tinggi, 16,9\% responden mempunyai perilaku pencegahan penyakit malaria kurang baik dan $52,2 \%$ responden mempunyai perilaku pencegahan penyakit malaria yang baik dengan p-value 0,000. Terdapat hubungan yang bermakna antara pengetahuan dan sikap terhadap perilaku upaya pencegahan penyakit malaria. Bagi Masyarakat dan jajaran petugas kesehatan, diharapkan partisipasi aktif dalam upaya peningkatan pengetahuan dan sikap terhadap upaya pencegahan penyakit malaria, melalui kolaborasi kegiatan yang berkesinambungan.
\end{abstract}

Kata Kunci : Perilaku Upaya Pencegahan Penyakit Malaria, Pengetahuan, Sikap

\begin{abstract}
Based on data obtained in the Jambi City Health Office in 2012 in 20 community health center with AMI, namely $13.57 \%$ with cases totaling 7300 cases. The study was conducted in the work area of the Koni community health center in Jambi City to determine the relationship between the independent variables (Knowledge and Attitude) and the dependent variable (Malaria Disease Prevention Behavior), with a total sample of 105 respondents. Research is a quantitative research with cross sectional design. Of the 36 respondents who had low knowledge, $52.5 \%$ of respondents had poor malaria prevention behavior and $10.9 \%$ of respondents had good malaria prevention behavior. Whereas from 69 respondents who have high knowledge, $47.5 \%$ of respondents have poor malaria prevention behavior and $89.1 \%$ of respondents have good malaria prevention behavior with a p-value of 0,000 . Whereas from 71 respondents who had low knowledge, $83.1 \%$ of respondents had poor malaria prevention behavior and $47.8 \%$ of respondents had good malaria prevention behavior. Whereas from 34 respondents who had high knowledge, $16.9 \%$ of respondents had poor malaria prevention behavior and $52.2 \%$ of respondents had good malaria prevention behavior with a p-value of 0,000 . There is a significant relationship between knowledge and attitudes towards the behavior of malaria prevention efforts. For the community and the ranks of health workers, it is expected that active participation in efforts to increase knowledge and attitudes towards malaria prevention efforts, through collaboration in sustainable activities.
\end{abstract}

Keywords: Prevention Behavior of Malaria, Knowledge, Attitude

Korespondensi : Dwi Noerjoedianto

Email : masyudi_psik99@yahoo.com 


\section{Latar Belakang}

Dewasa ini penyakit malaria telah menjadi masalah kesehatan dunia dan terjadi endemik di 105 negara, termasuk di Indonesia. Angka morbiditas dan mortalitas yang masih tinggi terutama di daerah luar Jawa dan Bali, terutama di daerah transmigrasi sering terjadi ledakan kasus atau wabah yang menimbulkan banyak kematian ${ }^{1}$.

Untuk mengatasi masalah malaria, dalam pertemuan World Health Assembly (WHA) ke60 tahun 2007 telah dihasilkan komitmen global tentang eliminasi malaria, yang tertuang dalam Kepmenkes

RI NO:293/MENKES/IV/2009 Tentang eliminasi malaria, dengan target seluruh sarana pelayanan kesehatan mampu melakukan pemeriksaan parasit malaria (semua penderita malaria klinis diperiksa sediaan darahnya atau konfirmasi laboratorium), dan target pada tahun 2020 harus sudah memasuki tahap praeliminasi, sedangkan tahun 2030 harus sudah mencapai eliminasi malaria di seluruh wilayah Indonesia.

Provinsi Jambi tahun 2010 dilaporkan sebanyak 41.691 kasus, sebesar 24.336 dari kasus tersebut diperiksa sediaan darahnya, dan dihasilkan 17.335 sediaan darah yang positif. Hasil kinerja menunjukkan tahun 2002 AMI di Provinsi Jambi berada pada angka 24,81 per 1000 penduduk sampai dengan tahun 2010 menunjukkan angka 13,99 per 1000 penduduk $^{2}$. Sedangkan data Dinas Kesehatan Kota Jambi pada tahun 2012 di 20 Puskesmas dengan AMI yaitu 13,57\% dengan kasus berjumlah 7300. Adapun daerah yang terbanyak kasus kejadian malaria tersebut adalah di Wilayah Kerja Puskesmas Koni kemudian Paal X dan Simpang IV Sipin³

Menyikapi hal tersebut perlu pengkajian lebih mendalam tentang pengetahuan dan sikap masyarakat terhadap Perilaku Upaya Pencegahan Penyakit Malaria di Wilayah Kerja Puskesmas Koni Kota Jambi.

Rumusan masalah, Bagaimana kajian Pengetahuan dan Sikap terhadap perilaku Upaya Pencegahan Penyakit Malaria di wilayah kerja Puskesmas Koni Kota Jambi Tahun 2013.

Tujuan penelitian ini Untuk mengetahui hubungan pengetahuan dan sikap masyarakat terhadap perilaku upaya pencegahan penyakit malaria di Puskesmas Koni Kota Jambi , sedangkan tujuan khusus adalah untuk (1) Mengetahui hubungan pengetahuan masyarakat terhadap perilaku upaya pencegahan malaria di puskesmas Koni Kota Jambi dan (2) Mengetahui hubungan sikap masyarakat terhadap perilaku upaya pencegahan malaria di Puskesmas Koni Kota Jambi.

Pengertian malaria, Malaria adalah merupakan salah satu penyakit infeksi yang disebabkan oleh Plasmodium. bersifat intraseluler, yang menularkan parasit ini adalah nyamuk Anopheles betina, dengan jenis Plasmodium falciparum, Plasmodium vivax, Plasmodium ovale, Plasmodium malariae ${ }^{4}$, 
melalui gigitan nyamuk Anopheles dengan waktu menyerang manusia malam hari mulai magrib (dusk) sampai fajar (dawn $)^{5}$.

Gejala malaria, dengan gejala demam, rentang kejadiannya tujuh hari sampai 14 hari sesudah gigitan nyamuk yang infektif. Gejala yang sering dijumpai adalah demam, sakit kepala, menggigil dan muntah, sehingga jika gejalanya ringan sukar di duga malaria. Jika tidak segera diobati, dalam waktu 24 jam penderita yang terinfeksi Plasmodium falciparum dapat berkembang cepat menjadi malaria berat dan bahkan dapat menimbulkan kematian bagi penderita 5 .

Diagnosis malaria, Pemeriksaan ini bertujuan untuk mengetahui kondisi umum penderita, meliputi pemeriksaan kadar hemoglobin, hematokrit, jumlah leukosit, eritrosit, dan trombosit. Juga bisa dilakukan pemeriksaan kimia darah (gula darah, SGOT, SGPT, tes fungsi ginjal, serta pemeriksaan foto toraks, EKG, dan pemeriksaan lainnya sesuai indikasi $^{6}$. Diagnosis malaria lainnya juga didasarkan anamnesis, pemeriksaan fisik dan pemeriksaan laboratorium ${ }^{7}$.

\section{Penyebaran Dan Penularan, Malaria} disebabkan oleh parasit sporozoa Plasmodium yang ditularkan melalui digitan nyamuk anopheles betina infektif. Sebagian besar nyamuk anopheles akan mengigit pada waktu senja atau malam hari, pada beberapa jenis nyamuk puncak gigitannya adalah tengah malam sampai fajar. Plasmodium akan mengalami dua siklus. Siklus aseksual (skizogoni) terjadi pada tubuh manusia, sedangkan siklus seksual (sporogoni) terjadi pada nyamuk. Siklus seksual dimulai dengan bersatunya gamet jantan dan betina untuk membentuk ookinet dalam perut nyamuk. Ookinet akan menembus dinding lambung untuk membentuk kista di selaput luar lambung nyamuk. Waktu yang diperlukan sampai pada proses ini adalah 8-35 hari, tergantung dari situasi lingkungan dan jenis parasitnya. Pada tempat inilah kista akan membentuk ribuan sporozoit yang terlepas dan kemudian tersebar ke seluruh organ nyamuk termasuk kelenjar ludah nyamuk. Pada kelenjar inilah sporozoit menjadi matang dan siap ditularkan bila nyamuk menggigit manusia. Selain ditularkan melalui gigitan nyamuk, malaria dapat menjangkit orang lain melalui bawaan lahir dari ibu ke anak, yang disebabkan karena kelainan pada sawar plasenta yang menghalangi penularan infeksi vertikal. Metode penularan lainnya adalah melalui jarum suntik, yang banyak terjadi pada pengguna narkoba suntik yang sering bertukar jarum secara tidak steril. Model penularan infeksi yang terakhir adalah melalui transfusi darah. Disebutkan dalam literatur bahwa melalui metode ini, hanya akan terjadi siklus eritrositer. Siklus hati tidak terjadi karena tidak melalui sporozoit yang memerlukan siklus hati(Widoyono, 2004).

Pencegahan malaria, melalui berbasis masyarakat ( Pola perilaku hidup bersih dan sehat, Menemukan dan mengobati penderita 
sedini mungkin akan sangat membantu mencegah penularan, Melakukan penyemprotan melalui kajian mendalam tentang kebiasaan nyamuk Anopheles mengigit, jarak terbang, dan resistensi terhadap insketisida ) dan Berbasis pribadi ( Pencegahan gigitan nyamuk, Informasi tentang donor darah )$^{6}$. Sedangkan pencegahan malaria secara umum meliputi tiga hal, yaitu edukasi, kemoprofilaksis, dan upaya menghindari gigitan nyamuk. Sedangkan 2 bentuk pengendalian vector yang efektif jika digunakan secara luas adalah (1) Kelambu yang diberi insektisida dan (2) Semprotan insekisida residual di dalam rumah (indoor residual spraying: IRS) ${ }^{8}$.

Pengetahuan, adalah merupakan hasil "tahu” yang terjadi setelah orang melakukan penginderaan terhadap suatu objek tertentu melalui panca indera manusia (penglihatan, pendengaran, penciuman. Rasa dan raba) ${ }^{9}$. Sedangkan tingkatan pengetahuan mencakup 6 (enam) fase yang dimulai dari tahu (know), memahami ( comprehention, aplikasi (Application), analisis (Analysis), sintesis (synthesis), evaluasi (evaluation). Pengukuran dapat dilakukan dengan wawancara atau angket yang menyatakan tentang isi materi yang diukur dari objek penelitian. Faktor yang mempengaruhi pengetahuan berasal dari Faktor internal ( Pendidikan, Pekerjaan, Umur, dan Pengalaman ) serta Faktor eksternal ( Faktor lingkungan, Sosial budaya, Media massa / informasi ) ${ }^{10}$.
Sedangkan faktor sikap merupakan reaksi atau respon yang masih tertutup dari seseorang terhadap suatu stimulus atau objek. Manifestasi sikap tidak langsung dilihat tetapi hanya dapat ditafsirkan terlebih dahulu dari perilaku yang tertutup.

Menurut Neowcomb yang dikutip oleh Notoatmodjo (2003) bahwa sikap merupakan kesiapan seseorang untuk bertindak sebagai objek di lingkungan tertentu, sebagai suatu penghayatan terhadap objek, yang terdiri dari 3 komponen pokok yaitu (1) Kepercayaan, ide dan konsep terhadap suatu objek, (2) Kehidupan emosional untuk evaluasi terhadap suatu objek dan (3) Kecenderungan untuk bertindak

Pengukuran sikap dapat dilakukan langsung atau tidak langsung. Secara langsung dapat dinyatakan melalui pendapat atau pertanyaan responden terhadap suatu objek, secara tidak langsung dapat dilakukan dengan pertanyaan-pertanyaan hipotesis, kemudian ditanyakan pendapat responden. Tingkatan sikap, terdiri dari menerima, merespon, menghargai, bertanggung jawab. Pengukuran sikap dapat dilakukan secara langsung dan tidak langsung dengan hasil skala likert yang terdiri dari 5 poin (sangat setuju, setuju, raguragu, tidak setuju, sangat tidak setuju ${ }^{11}$.

Perilaku adalah tindakan atau perbuatan suatu organisme yang dapat diamati dan dipelajari, sedangkan yang dimaksud dengan perilaku kesehatan adalah suatu respon seseorang terhadap stimulus yang berkaitan 
dengan sakit, penyakit, sistem pelayanan kesehatan, makanan serta lingkungan ${ }^{12}$.Faktor yang mempengaruhi perilaku ( Lawrence W. Green) mengidentifikasi 3 faktor yang mempengaruhi baik individual maupun kolektif, yaitu predisposing factor, enabling factor, dan enabling factor. Proses perubahan perilaku hasil penelitian rogers mengungkapkan bahawa sebelum orang beradaptasi perilaku baru di dalam diri orang tersebut terjadi proses yang berurutan, yaitu kesadaran, merasa senang, menimbang nimbang, mencoba dan menerima,

\section{METODE PENELITIAN}

Penelitian ini adalah penelitian kuantitatif dengan desain cross sectional, dilakukan di

\section{HASIL DAN PEMBAHASAN}

\section{KARAKTERISTIK RESPONDEN}

a. Umur

Berikut ini gambaran umur responden yang menderita penyakit malaria di wilayah puskesmas Koni Kota Jambi tahun 2013, dengan jumlah populasi $12.872 \mathrm{KK}$, sedangkan besar sampel 95 responden, teknik pengambilan sampel secara cluster random sampling. Kriterisa Inklusi responden adalah sebagai berikut (1) Tercatat di buku status klien pada Puskesmas Koni, (2) Kepala keluarga atau Ibu Rumah tangga, (3) Bersedia menjadi responden, (4) Responden menderita penyakit malaria, (5) Responden bertempat tinggal di Kecamatan yang termasuk wilayah kerja Puskesmas Koni Kota Jambi. Metode Pengambilan Data melalui Data Primer dan data sekunder, Instrument Penelitian menggunakan Kuesioner, Analisis Data menggunakan Analisis Univariat dan Analisis Bivariat dengan Uji statistik chi-square

Tabel 1 Distribusi Frekuensi Responden Berdasarkan Umur Di Puskesmas Koni Kota Jambi

\begin{tabular}{|c|c|c|c|}
\hline No & Umur (Tahun) & Jumlah & $(\%)$ \\
\hline 1 & $21-30$ & 34 & 32.4 \\
\hline 2 & $31-40$ & 27 & 25.7 \\
\hline 3 & $41-50$ & 32 & 30.5 \\
\hline 4 & $51-60$ & 9 & 8.6 \\
\hline 5 & $61-70$ & 3 & 2.9 \\
\hline \multicolumn{2}{|r|}{ Jumlah } & 105 & 100 \\
\hline
\end{tabular}


b. Jenis Kelamin

Tabel 2 Distribusi Frekuensi Responden Berdasarkan Jenis Kelamin Di Puskesmas Koni Kota Jambi

\begin{tabular}{c|l|c|c}
\hline No & Jenis Kelamin & Jumlah & $(\boldsymbol{\%})$ \\
\hline 1 & Perempuan & 53 & 50.5 \\
\hline 2 & Laki - Laki & 52 & 49.5 \\
\hline \multicolumn{2}{r|}{ Jumlah } & $\mathbf{1 0 5}$ & $\mathbf{1 0 0}$ \\
\hline
\end{tabular}

Berdasarkan tabel diatas banyak pada perempuan yaitu sebanyak 53 memperlihatkan bahwa dari 105 responden orang $(50,5 \%)$ ternyata kelompok jenis kelamin yang paling

c. Tingkat Pendidikan

Tabel 3 Distribusi Frekuensi Responden Berdasarkan Pendidikan Di Puskesmas Koni Kota Jambi

\begin{tabular}{c|l|c|c}
\hline No & \multicolumn{1}{|c|}{ Pendidikan } & Jumlah & \% \\
\hline 1 & SD & 18 & 17.1 \\
\hline 2 & SMP Sederajat & 14 & 13.3 \\
\hline 3 & SMA Sederajat & 29 & 27.6 \\
\hline 4 & Diploma & 18 & 17.1 \\
\hline 5 & Sarjana & 26 & 24.8 \\
\hline \multicolumn{2}{r|}{ Jumlah } & $\mathbf{1 0 5}$ & $\mathbf{1 0 0}$ \\
\hline
\end{tabular}

Berdasarkan tabel 3 pada SMA yaitu sebanyak 29 orang memperlihatkan bahwa dari 105 responden $\quad(27,6 \%)$.

ternyata pendidikan yang paling banyak

\section{PEMBAHASAN}

\section{a. Analisis Univariat}

Analisis univariat digunakan untuk melihat distribusi frekuensi dan persentase masingmasing variabel penelitian. 


\section{a.1. Pengetahuan}

Tabel 4 Distribusi Responden Berdasarkan Pengetahuan masyarakat Tentang Perilaku Upaya Pencegahan Penyakit Malaria Di Puskesmas Koni Kota Jambi Tahun 2013

\begin{tabular}{c|l|c|c}
\hline No & \multicolumn{1}{|c|}{ Pengetahuan } & Jumlah & \% \\
\hline 1 & Rendah & 36 & 34.3 \\
\hline 2 & Tinggi & 69 & 65.7 \\
\hline \multicolumn{2}{r|}{ Jumlah } & $\mathbf{1 0 5}$ & $\mathbf{1 0 0}$ \\
\hline
\end{tabular}

Berdasarkan tabel 4 bahwa pengetahuan masyarakat tentang penyakit malaria lebih banyak yang tinggi yaitu 65,7\% ( 69 orang ) jika dibandingkan dengan tingkat pengetahuan rendah 34,3\% ( 36 orang ), sehingga dapat disimpulkan bahwa responden yang memiliki pengetahuan tinggi lebih besar dari pada responden yang memiliki pengetahuan rendah

Menurut Notoatmodjo $^{12}$, bahwa pengetahuan atau kognitif merupakan domain yang sangat penting untuk terbentuknya perilaku seseorang, sehingga akan mempengaruhi perilaku masyarakat dalam mencegah penyakit malaria, terutama dalam hal pengertian malaria, tanda dan gejala malaria, pencegahan malaria, penyebaran dan penularan malaria serta penatalaksanaan malaria.

\section{a.2. Sikap}

Tabel 5 Distribusi Responden Berdasarkan Sikap Tentang Perilaku Upaya Pencegahan Penyakit Malaria Di Puskesmas Koni Kota Jambi Tahun 2013

\begin{tabular}{c|c|c|c}
\hline No & \multicolumn{1}{|c|}{ Sikap } & Jumlah & \% \\
\hline 1 & Kurang Baik & 71 & 67.6 \\
\hline 2 & Baik & 34 & 32.4 \\
\hline \multicolumn{2}{c|}{ Total } & $\mathbf{1 0 5}$ & $\mathbf{1 0 0}$ \\
\hline
\end{tabular}

Berdasarkan tabel 5 terlihat bahwa sikap masyarakat terhadap penyakit malaria masih tergolong kurang baik sebanyak 67,6\% sedangkan yang tergolong baik hanya $32,4 \%$, sehingga dapat disimpulkan bahwa responden yang memiliki sikap kurang baik dalam perilaku pencegahan penyakit malaria lebih banyak dari pada responden yang memiliki sikap baik dalam perilaku pencegahan penyakit malaria.

Menurut Allport dalam Notoatmodjo ${ }^{12}$, menjelaskan bahwa sikap mempunyai 3 komponen pokok yaitu kepercayaan (keyakinan), ide dan konsep terhadap suatu 
objek kehidupan emosional atau evaluasi terhadap suatu objek dan kecendrungan untuk bertindak. Ketiga komponen ini secara bersama-sama membentuk sikap yang utuh. Dalam menentukan sikap yang utuh ini, pengetahuan, pikiran, keyakinan, dan emosi memegang peranan yang penting, terutama adanya anggapan penyakit malaria tidak berbahaya sehingga responden kurang baik untuk mencegah penyakit malaria.

\section{a.3. Perilaku Upaya Pencegahan Penyakit Malaria}

Tabel 6 Distribusi Responden Berdasarkan Perilaku Upaya Pencegahan Penyakit Malaria Di Puskesmas Koni Kota Jambi Tahun 2013

\begin{tabular}{c|l|c|c}
\hline No & $\begin{array}{c}\text { Perilaku Upaya } \\
\text { Pencegahan Penyakit } \\
\text { Malaria }\end{array}$ & Jumlah & \% \\
\hline 1 & Kurang Baik & 59 & 56.2 \\
\hline 2 & Baik & 46 & 43.8 \\
\hline \multicolumn{2}{c|}{ Total } & $\mathbf{1 0 5}$ & $\mathbf{1 0 0}$ \\
\hline
\end{tabular}

Berdasarkan tabel 6 terlihat bahwa perilaku masyarakat dalam upaya pencegahan penyakit malaria masih kurang baik sebanyak $56,2 \%$ sedangkan perilaku masyarakat yang baik dalam upaya pencegahan penyakit malaria hanya $43,8 \%$, sehingga dapat disimpulkan bahwa responden yang memiliki perilaku pencegahan penyakit malaria kurang baik lebih besar dari pada responden yang memiliki perilaku pencegahan penyakit malaria baik, terutama dalam hal tidur memakai kelambu untuk mencegah gigitan nyamuk malaria, mengurangi tempat perindukan nyamuk malaria, mengolesi badan dengan obat anti nyamuk, menggunakan pembasmi serangga, memasang kawat kasa pada jendela dan ventilasi, dan mencegah penderita malaria dari gigitan nyamuk agar infeksi tidak menyebar lebih jauh.
Perilaku responden yang kurang baik dapat menyebabkan responden berpotensi untuk menderita penyakit malaria. Karena dengan perilaku yang kurang baik dalam mencegah penyakit malaria memudahkan nyamuk malaria untuk menularkan penyakit malaria.

Hasil penelitian ini, pada umumnya responden berperilaku kurang baik pada saat berada di luar rumah dengan tidak memakai baju lengan panjang dan celana panjang dan ketika tidur di malam hari tidak menggunakan kelambu serta tidak mengolesi badan dengan obat anti nyamuk, tidak menggunakan obat anti nyamuk bakar, maupun semprot.

Untuk itu perlu adanya upaya untuk merubah perilaku responden kearah yang lebih baik dengan tujuan untuk mencegah penyakit malaria. Petugas kesehatan mempunyai andil 
yang sangat besar dalam hal mencegah meningkatnya penderita dan memberikan pendidikan kesehatan pada masyarakat guna meningkatkan pengetahuan tentang pencegahan penyakit malaria, sehingga masyarakat dapat melakukan tindakan untuk menghindari gigitan nyamuk. Kemudian juga dapat dilakukan ketika masyarakat mendatangi pelayanan kesehatan atau pada saat melakukan pemeriksaan yang berhubungan dengan penyakit malaria.

\section{b. Analisis Bivariat}

Untuk mengetahui apakah variabel dengan menggunakan uji statistic Chi-square independen berhubungan dengan variabel dengan hasil sebagai berikut : dependen, maka dilakukan analisis bivariat

b.1. Hubungan Pengetahuan Terhadap Perilaku Upaya Pencegahan Penyakit Malaria Di Puskermas Kota Jambi

Tabel 7 Distribusi Hubungan Pengetahuan Terhadap Perilaku Upaya Pencegahan Penyakit Malaria Di Puskesmas Koni Kota Jambi

\begin{tabular}{|c|c|c|c|c|c|c|c|c|}
\hline \multirow[t]{3}{*}{ No } & \multirow{3}{*}{$\begin{array}{c}\text { Pengeta } \\
\text { huan }\end{array}$} & \multicolumn{4}{|c|}{$\begin{array}{c}\text { Perilaku Upaya } \\
\text { Pencegahan Penyakit } \\
\text { Malaria }\end{array}$} & \multicolumn{2}{|c|}{ Jumlah } & \multirow[t]{3}{*}{ p-value } \\
\hline & & \multicolumn{2}{|c|}{ Kurang Baik } & \multicolumn{2}{|c|}{ Baik } & \multirow{2}{*}{$\mathrm{Jml}$} & \multirow{2}{*}{$\%$} & \\
\hline & & $\mathrm{Jml}$ & $\%$ & $\mathrm{Jml}$ & $\%$ & & & \\
\hline 1 & Rendah & 31 & 52,5 & 5 & 10,9 & 36 & $\begin{array}{c}34 \\
3\end{array}$ & \\
\hline 2 & Tinggi & 28 & 47,5 & 41 & 89,1 & 69 & $\begin{array}{c}65 \\
7\end{array}$ & 0,000 \\
\hline & Jumlah & 59 & 100 & 46 & 100 & 105 & 100 & \\
\hline
\end{tabular}

Hasil analisis tabel 7 menunjukkan bahwa dari 36 masyarakat yang memiliki pengetahuan rendah, 52,5\% masyarakat mempunyai perilaku pencegahan penyakit malaria yang kurang baik dan 10,9\% masyarakat mempunyai perilaku pencegahan penyakit malaria yang baik. Sedangkan dari 69 masyarakat yang memiliki pengetahuan tinggi, $47,5 \%$ masyarakat mempunyai perilaku pencegahan penyakit malaria kurang baik dan $89,1 \%$ masyarakat mempunyai perilaku pencegahan penyakit malaria yang baik.

Berdasarkan uji statistik Chi-square diperoleh nilai $p$-value $=0,000$ dengan 
demikian $p$ value > alpha (5\%) artinya Ho ditolak, maka dapat disimpulkan bahwa ada hubungan yang bermakna antara pengetahuan dengan perilaku upaya pencegahan penyakit malaria di Wilayah Kerja Puskesmas Koni Kota Jambi.

Hasil penelitian ini menunjukkan bahwa hubungan pengetahuan dengan perilaku upaya pencegahan penyakit malaria dari 31 responden dengan pengetahuan rendah sebagian besar $(52,5 \%)$ berperilaku kurang baik dalam upaya pencegahan penyakit malaria. Sedangkan dari 41 responden dengan pengetahuan tinggi sebagian besar $(89,1 \%)$ berperilaku baik dalam upaya pencegahan penyakit malaria. Hasil uji statistik diperoleh nilai $\mathrm{p}$-value $=0,000$, dapat dikatakan bahwa ada hubungan yang bermakna antara pengetahuan dengan perilaku upaya pencegahan penyakit malaria. Sehingga dapat disimpulkan bahwa semakin tinggi pengetahuan responden tentang perilaku pencegahan penyakit malaria maka semakin baik responden berperilaku dalam pencegahan penyakit malaria.

Level dan Clark $^{13}$, dalam Preventive Medicine, mengemukakan ada 2 periode seseorang menjadi sakit yaitu prepathogenesis dan if pathogenesis di mana 2 periode tersebut bisa di cegah melalui 3 tahapan yaitu : primary preventive, secondary preventive, dan tertiary preventive yang masing-masing tahapan diupayakan untuk mencegah seseorang untuk tidak menjadi sakit misalnya tertularnya penyakit malaria klinis.
Menurut Prabowo ${ }^{14}$ penularan penyakit malaria dapat melalui dua cara yaitu penularan secara alamiah yaitu melalui gigitan nyamuk anopheles dan non alamiah berupa malaria bawaan (kongenital). Penyakit ini dapat di cegah dengan menghindari gigitan nyamuk seperti memakai baju berlengan panjang dan celana panjang pada saat keluar rumah terutama pada malam hari, tidur memakai kelambu, memakai obat anti nyamuk baik lotion, bakar maupun semprot, menimbun genangan air di sekitar rumah, menutup serta membersihkan tempat penampungan air dan tidak menggantungkan pakaian yang kotor.

Notoatmodjo $^{12}$, mengemukakan bahwa pengetahuan atau kognitif merupakan domain yang sangat penting untuk terbentuknya perilaku seseorang. Pengetahuan yang baik tentang cara pencegahan penyakit malaria akan mempengaruhi perilaku masyarakat dalam mencegah penyakit malaria. Dengan meningkatkan pengetahuan responden dengan penyakit malaria diusahakan kasus-kasus penyakit malaria bisa dikurangi bahkan dapat di cegah.

\begin{tabular}{ccr} 
Lebih & lanjut & \multicolumn{2}{c}{ Notoatmodjo $^{15}$, } \\
mengemukakan & bahwa untuk menilai
\end{tabular}
kedalaman pengetahuan dimulai dari rasa ingin tahu, memahami aplikasi, dan evaluasi. Aplikasi seseorang yang lebih tahu, maka ia akan berespon untuk melakukan sesuatu, dengan demikian akan timbul dorongan atau keinginan untuk mewujudkannya dan dalam mewujudkan perilaku kesehatan tersebut 
petugas pemberi pelayanan kesehatan sangat berarti sekali untuk meningkatkan pengetahuan, kesadaran, dan kemauan untuk hidup sehat.

Penelitian ini mendukung hasil penelitian yang dilakukan oleh Ade $^{16}$, Karsidin ${ }^{17}$ dan Novianti $^{18}$ yang menyatakan bahwa ada hubungan yang signifikan antara pengetahuan responden dengan pencegahan penyakit malaria.

Menurut peneliti, sebelum seseorang mengadopsi perilaku, ia harus tahu terlebih dahulu apa arti atau manfaat perilaku tersebut bagi dirinya. Untuk itu peningkatan pengetahuan responden tentang upaya pencegahan penyakit malaria pada responden sangat diperlukan sehingga pencegahan penyakit malaria dapat dilakukan.
Untuk meningkatkan pengetahuan responden, perlu dilakukan penyuluhanpenyuluhan secara intensif pada masyarakat tentang perilaku pencegahan penyakit malaria. Penyuluhan dapat dilakukan langsung ke rumah-rumah warga, pertemuan rutin di RT, atau ke pelayanan kesehatan yang ada di sekitar rumah, seperti posyandu dan puskesmas sehingga pengetahuan responden akan meningkat tentang perilaku pencegahan penyakit malaria. Selain itu juga dapat dilakukan ketika masyarakat mendatangi pelayanan kesehatan atau pada saat melakukan pemeriksaan kesehatan yang berhubungan dengan penyakit malaria perawat dapat memberikan pengetahuan tentang penyakit malaria.

\section{b.2. Hubungan Sikap Terhadap Perilaku Upaya Pencegahan Penyakit Malaria Di Puskesmas Koni} Kota Jambi

Tabel 8 Distibusi Hubungan Sikap Terhadap Perilaku Upaya Pencegahan Penyakit Malaria Di Puskesmas Koni Kota Jambi

\begin{tabular}{|c|c|c|c|c|c|c|c|c|}
\hline \multirow{3}{*}{ No } & \multirow{3}{*}{ Sikap } & \multicolumn{4}{|c|}{$\begin{array}{c}\text { Perilaku Upaya } \\
\text { Pencegahan Penyakit } \\
\text { Malaria }\end{array}$} & \multicolumn{2}{|c|}{ Jumlah } & \multirow{3}{*}{ p-value } \\
\hline & & \multicolumn{2}{|c|}{$\begin{array}{c}\text { Kurang } \\
\text { Baik }\end{array}$} & \multicolumn{2}{|c|}{ Baik } & \multirow[t]{2}{*}{ Jml } & \multirow[t]{2}{*}{$\%$} & \\
\hline & & $\mathrm{Jml}$ & $\%$ & $\mathrm{Jml}$ & $\%$ & & & \\
\hline 1 & Rendah & 49 & 83,1 & 22 & 47,8 & 71 & $\begin{array}{c}67 \\
6\end{array}$ & \\
\hline 2 & Tinggi & 10 & 16,9 & 24 & 52,2 & 34 & $\begin{array}{c}32 \\
4\end{array}$ & 0,000 \\
\hline & umlah & 59 & 100 & 46 & 100 & 105 & 100 & \\
\hline
\end{tabular}


Hasil analisis tabel 8 menunjukkan bahwa dari 71 masyarakat yang memiliki pengetahuan rendah, $83,1 \%$ masyarakat mempunyai perilaku pencegahan penyakit malaria yang kurang baik dan $47,8 \%$ masyarakat mempunyai perilaku pencegahan penyakit malaria yang baik. Sedangkan dari 34 masyarakat yang memiliki pengetahuan tinggi, $16,9 \%$ masyarakat mempunyai perilaku pencegahan penyakit malaria kurang baik dan $52,2 \%$ masyarakat mempunyai perilaku pencegahan penyakit malaria yang baik.

Berdasarkan uji statistik Chi-square diperoleh nilai $p$-value $=0,000$ dengan demikian $p$ value > alpha (5\%) artinya Ho ditolak, maka dapat disimpulkan bahwa ada hubungan yang bermakna antara sikap dengan perilaku upaya pencegahan penyakit malaria di Wilayah Kerja Puskesmas Koni Kota Jambi.

Hasil penelitian ini menunjukkan bahwa hubungan sikap masyarakat dengan perilaku upaya pencegahan penyakit malaria diketahui dari 49 responden dengan sikap yang rendah sebagian besar $(83,1 \%)$ berperilaku kurang baik dalam upaya pencegahan penyakit malaria. Sedangkan dari 24 responden dengan sikap yang baik sebagian besar $(52,2 \%)$ berperilaku baik dalam upaya pencegahan penyakit malaria. Hasil uji statistik diperoleh nilai $\mathrm{P}$-value $=0,000$, dimana dapat disimpulkan bahwa ada hubungan yang bermakna antara sikap dengan perilaku upaya pencegahan penyakit malaria. Sehingga dapat disimpulkan bahwa semakin baik sikap responden tentang perilaku pencegahan penyakit malaria maka semakin baik responden berperilaku dalam pencegahan penyakit malaria.

Di dalam program Gebrak Malaria ${ }^{19}$ bahwa pengetahuan, sikap dan perilaku sangat berhubungan dengan proses penularan penyakit malaria dan perilaku vector dalam proses terjadinya penularan sehingga dapat diketahui upaya pencegahan penyakit malaria maupun upaya pengobatannya.

Bloom B dalam Notoatmodjo ${ }^{15}$, mengatakan bahwa sikap merupakan reaksi atau respon yang masih tertutup dari seseorang terhadap suatu stimulus atau objek. Allport dalam Notoatmodjo ${ }^{15}$, menjelaskan bahwa sikap mempunyai 3 komponen pokok yaitu kepercayaan (keyakinan), ide, dan konsep terhadap suatu objek kehidupan emosional atau evaluasi terhadap suatu objek dan kecenderungan untuk bertindak. Ketiga komponen ini secara bersama-sama membentuk sikap yang utuh. Dalam menentukan sikap yang utuh ini, pengetahuan, pikiran, keyakinan dan emosi memegang peranan yang penting.

Lebih lanjut dalam Gebrak Malaria ${ }^{19}$, adanya perubahan lingkungan dan pembangunan yang tidak berwawasan kesehatan serta tingginya mobilitas penduduk yang masuk daerah non endemis malaria ke endemis malaria atau sebaliknya dapat meningkatkan insiden penyakit malaria. 
Selain itu Fahmi $^{20}$, adanya mobilitas penduduk yang tinggi sangat berpengaruh terhadap penyebaran penyakit malaria, selain itu dari segi kebiasaan, sikap dan perilaku sangat terikat dalam kejadian penyakit malaria.

Menurut Hidayat ${ }^{21}$, sikap dapat diukur dengan menggunakan skala likert dimana bentuk pernyataan sikap antara lain sangat setuju, setuju, tidak setuju, dan sangat tidak setuju. Sikap responden sangat dibutuhkan untuk meningkatkan perilaku pencegahan penyakit malaria. Semakin berperilaku kurang baik sikap responden dalam pencegahan penyakit malaria maka semakin mudah untuk menderita penyakit malaria.

Hasil penelitian ini mendukung hasil penelitian yang dilakukan Novianti ${ }^{18}$, yang menyatakan bahwa ada hubungan yang signifikan antara sikap responden dengan pencegahan penyakit malaria.

Hasil penelitian ini diketahui bahwa sikap responden dengan perilaku pencegahan penyakit malaria masih kurang baik yaitu sebanyak 49 responden $(83,1 \%)$ memiliki sikap

\section{KESIMPULAN DAN SARAN}

\section{Kesimpulan}

1. Terdapat hubungan yang bermakna antara pengetahuan terhadap perilaku upaya pencegahan penyakit malaria di Puskesmas Koni Kota Jambi. kurang baik dengan perilaku pencegahan penyakit malaria. Sementara itu pada saat dilakukan penelitian masih banyak responden kurang baik dalam mencegah penyakit malaria. Hal ini dikarenakan masih kurangnya kepedulian masyarakat terhadap lingkungan sehingga masih banyaknya lingkungan yang tidak sehat seperti adanya jentik nyamuk malaria di dalam bak mandi, pakaian kotor banyak tergantung, ventilasi tidak dipasang kawat kassa, terdapat kaleng-kaleng bekas di sekitar rumah dan adanya genangan air disekitar rumah.

Untuk meningkatkan sikap responden berperilaku menjadi lebih baik dalam pencegahan penyakit malaria perlu dilakukan penyuluhan baik dari leaflet, poster atau dari media elektronik sehingga responden akan lebih mudah dan mampu untuk mencegah penyakit malaria dan meningkatkan kepedulian masyarakat terhadap lingkungan serta meningkatkan frekuensi penyuluhanpenyuluhan dengan melakukan evaluasi stiap penyuluhan yang dilakukan.

2. Terdapat hubungan yang bermakna antara sikap masyarakat terhadap perilaku upaya pencegahan penyakit malaria di Puskesmas Koni Kota Jambi. 


\section{Saran}

Bagi Masyarakat dan jajaran petugas kesehatan, diharapkan partisipasi aktif dalam upaya peningkatan pengetahuan dan sikap terhadap upaya pencegahan penyakit malaria, melalui kolaborasi kegiatan yang berkesinambungan.

\section{Daftar Pustaka}

1. Widoyono, Penyakit Tropis Epidemiologi, Penularan, Pencegahan, Dan Pemberantasannya, Edisi Ke-2. Semarang. Erlangga. 2011

2. Dinas Kesehatan Provinsi Jambi. Profil Kesehatan Jambi. Jambi. 2011

3. Dinas Kesehatan Kota Jambi. Profil Kesehatan Kota Jambi. 2012

4. Davey P. At A Glance Medicine. Blackwell Scince Ltd. 2006

5. Soedarto. Malaria : Referensi Mutakhir Epidemiologi Global-PlasmodiumAnopheles-Penatalaksanaan Malaria. Jakarta. Cv Sagung Seto. 2012

6. Greenberg M I. Teks-Atlas- Kedokteran Kedaruratan. Usa. Lippicott Williams Dan Wilkins. 2012

7. Kementerian Kesehatan Republik Indonesia. Pedoman Penatalaksanaa Kasus Malaria Di Indonesia. 2011

8. Widoyono. Penyakit Tropis Epidemiologi, Penularan, Pencegahan Dan Pemberantasannya. Jakarta. Erlangga. 2011

9. Notoatmodjo. Ilmu Perilaku Kesehatan. Jakarta. Rineka Cipta. 2010

10. Erfandi. Pengetahuan Dan Faktor - Faktor Yang Mempengaruhi. Diakses Pada Tanggal 15 April 2013 Diunduh Dari Http://Forbetterhealth. Wordpress.Com/2009/04/19/PengetahuanDan-Faktor-Yang-Mempengaruhi/. 2009

11. Notoatmodjo. Promosi Kesehatan dan Ilmu Perilaku. Jakarta. Rineka Cipta. 2007
12. Notoadmodjo, S. Promosi Kesehatan Teori dan Aplikasi. Jakarta Rineka Cipta. 2005

13. Level dan Clark. Preventive medicine. Jakarta. EGC. 2002

14. Prabowo. Malaria, Mencegah Dan Mengatasinya. Jakarta. Puspa Swara. 2004

15. Notoatmodjo. Metodologi Penelitian Kesehatan. Jakarta. Rineka Cipta. 2003

16. Ade, P. Hubungan Pengetahuan dan Sikap dengan Kejadian Malaria Klinis di Kelurahan Kenali Besar. Jambi. Skripsi STIKES Harapan Ibu. 2005

17. Karsidin. Hubungan Pengetahuan dan Tindakan Pencegahan Keluarga Dengan Kejadian Malaria Klinis Di Puskesmas Penyengat Olak Muaro jambi. Jambi. Skripsi Sekolah Tinggi Ilmu Kesehatan Harapan Ibu. 2007

18. Novianti. Hubungan Pengetahuan, Sikap, dan Peran Perawat dengan Pencegahan Penyakit Malaria di Wilayah kerja Puskesmas Simpang IV Sipin Kota Jambi. Skripsi. STIKBA Jambi. 2010

19. Depkes RI. Gebrak Malaria, Pedoman Teknis Pemeriksaan Parasit Malaria. Jakarta. Ditjen PP \& PL. 2007

20. Fahmi. Malaria mengancam Kemiskinan Garda No. 240 Tahun 2004. 2004

21. Hidayat, A. Metode Penelitian Keperawatan Dan Teknik Analisis Data. Jakarta. Salemba Medika. 2008 